\title{
Learning Video Based on Contextual Approach Science Content of Grade V Elementary School
}

\author{
Gede Ngurah Griantara Manuaba ${ }^{1 *}$, DB.Kt.Ngr. Semara Putra ${ }^{2 *}$ (iD \\ 1,2 Pendidikan Guru Sekolah Dasar, Universitas Pendidikan Ganesha, Singaraja, Indonesia \\ *Corresponding author: gedengurahgriantaramanuaba25@undiksha.ac.id
}

\begin{abstract}
Abstrak
Kurangnya pemanfaatan media video dalam proses pembelajaran menyebabkan siswa kesulitan dalam belajar. Penelitian ini bertujuan untuk mengembangkan media pembelajaran audiovisual yang disesuaikan dengan kebutuhan pada pembelajaran saat ini. Subjek uji pada penelitian ini yaitu terdiri dari beberapa para ahli dan siswa. Para ahli tersebut terdiri dari ahli isi pembelajaran, ahli desain pembelajaran dan ahli media pembelajaran serta melibatkan siswa kelas untuk melakukan uji perorangan dan uji coba kelompok kecil. Penelitian pengembangan ini menggunakan model pengembangan ADDIE (analyze, design, development, implementation, evaluation) sebagai langkah-langkah sistematis pada proses pengembangan produk. Metode pengumpulan data pada penelitian ini terdiri dari observasi, angket dan wawancara. Teknik analisis data yang digunakan yakni teknik analisis data deskriptif kuantitatif dan kualitatif. Berdasarkan hasil uji coba produk, video pembelajaran dinyatakan layak oleh subjek uji, yakni ahli isi pembelajaran, ahli desain pembelajaran, ahli media pembelajaran dan siswa. Hasil penilaian ahli isi pembelajaran memperoleh persentase (95,83\%) dengan kualifikasi sangat baik, hasil penilaian ahli desain pembelajaran memperoleh persentase $(94,23 \%)$ dengan kualifikasi sangat baik, hasil penilaian ahli media pembelajaran memperoleh persentase (85,00\%) dengan kualifikasi baik dan hasil penilaian siswa melalui uji perorangan memperoleh persentase $(94,00 \%)$ dengan kualifikasi sangat baik, serta hasil penilaian siswa melalui uji kelompok kecil memperoleh persentase (95,83\%). Berdasarkan hasil uji coba produk disimpulkan bahwa video pembelajaran yang dikembangkan memperoleh kualifikasi sangat baik dan layak digunakan dalam proses pembelajaran.
\end{abstract}

Kata kunci: Video Pembelajaran, Kontekstual, IPA

\section{Abstract}

The lack of use of video media in the learning process causes students to have difficulties in learning. This research aims to develop audiovisual learning media tailored to the needs of today's learning. The test subjects in this study consisted of several experts and students. The experts consist of learning content experts, learning design experts and learning media experts and involve grade $\mathrm{V}$ students to conduct individual trials and small group trials. This development research uses ADDIE development model (analyze, design, development, implementation, evaluation) as systematic steps in the product development process. The data collection method in this study consists of observations, questionnaires and interviews. The data analysis techniques used are quantitative and qualitative descriptive data analysis techniques. Based on the results of product trials, the instructional video was declared feasible by the test subjects, namely learning content experts, learning design experts, learning media experts and students. The results of the evaluation of the learning content expert obtained a percentage $(95.83 \%)$ with very good qualification, the results of the learning design expert's assessment obtained a percentage $(94.23 \%)$ with very good qualification, the results of the learning media expert's assessment obtained a percentage $(85.00 \%)$ with good qualifications and the results of student assessments through individual tests obtained a percentage (94.00\%) with very good qualification, and the results of student assessments through small group tests obtained a percentage $(95.83 \%)$. Based on the results of the product trial, it is concluded that the developed learning videos in very good qualifications and suitable for use in the learning process.

Keywords: Videos, Animation, Contextual, natural science

\begin{tabular}{lll}
\hline History: & & Publisher: Undiksha Press \\
Received & : March 20, 2021 & Licensed: This work is licensed under \\
Revised & : March 22, 2021 & a Creative Commons Attribution 3.0 License \\
Accepted & : June 15, 2021 & Published \\
: July 25, 2021 &
\end{tabular}




\section{Introduction}

Science is a subject in Elementary School. Science is built on scientific attitudes, scientific processes, and scientific products (Desnita \& Susanti, 2017; Setiawan et al., 2017). Science is a learning concept related to nature and has a very broad relationship related to human life. Science is also defined as an initial exercise for students to think in developing students' early copyright and interest in the surrounding environment (Chandra et al., 2020; Maison et al., 2020). Science was introduced at the level of formal education starting from an early age which was then continued in the learning process in elementary school as one of the intact subjects (Lo et al., 2021; Puspitarini \& Hanif, 2019). Science learning process emphasizes on providing hands-on experience to develop competencies in order to explore and understand the environment naturally (Rusli et al., 2020; Suryawati \& Osman, 2018).

Science learning that gives students the opportunity to construct their own concepts, will provide hands-on experience to explore and understand the environment scientifically (Lo et al., 2021; Subali et al., 2019). Science learning can not be by memorizing or passively listening to the teacher explain the concept only but the students themselves who have to do the learning through experimentation, observation or active experimentation (Dewi et al., 2018; Hwang et al., 2013). One of the reasons Science is incorporated into the Elementary School curriculum, is that Science is the basic knowledge of a technology (Lai et al., 2019; Zulfiani et al., 2020). Science content plays a role in the educational process as well as the development of technology. The content of Natural Sciences is expected to be a vehicle for students to learn themselves and the environment, as well as further development on their application in daily life. Seeing the importance of science learning to be learned by students, then in the learning process, science materials must be explained systematically so that it is easy to understand by students and can support the achievement of educational objectives (Anif et al., 2020; Gordon et al., 2013).

Observations and interviews conducted at SD No.5 Abiansemal with teachers in grade $\mathrm{V}$ showed a gap because of the data obtained that teachers find it difficult to explain teaching materials, especially the content of Natural Sciences changes in the form of objects in this pandemic because of the lack of learning media that can be accessed by students from home. The use of learning media has not been done to the maximum as a means of learning (Marshel \& Ratnawulan, 2020; Shodiq \& Zainiyati, 2020). The school only provides textbooks as a basic learning resource and student worksheets as support. The books are texts that tend to be informative so that they attract less attention from students in learning. The difficulty of teachers using a media for the learning process makes it difficult for students to understand the content of the material because students learn without the support of learning media that is easy to access students from home. Judging from the problem, it is considered very important to be pursued in the form of media development in the form of contextual approach-based learning videos on the content of ipa grade $\mathrm{V}$ elementary school as an effort to support the learning process to be more effective and fun.

Education today consists of teaching from specialized experts, and cannot be seen but rather more in-depth such as providing knowledge, consideration and wisdom (Kivunja, 2013; Marhayani, 2016). The end of the educational process students have spiritual abilities, self-control, personality, intelligence, noble morals and skills they need in the lives of society, nation and country (Ikeda et al., 2018; Zendler \& Greiner, 2020). The use of technology also plays a role in education, especially in the learning process that can be interpreted as a process to encourage active learning, construct knowledge, incugate students so as to make it possible to communicate remotely between teachers and students (Mpungose, 2021; Zhang et al., 2021). In a learning process, there is certainly a need for an approach to support the achievement of learning objectives. One approach that can be applied in the learning process is the contextual approach. 
Contextual approach is an approach in the learning process that connects material concepts with real life and makes connections in daily life (I Made Arnawa, 2017; Nugroho, 2018). Using contextual approaches in teaching teacher learning by avoiding conveying information to students, but teachers view students as subjects (Rahayu \& Febriaty, 2017; Tapingkae et al., 2020). Natural Science Learning emphasizes its learning using its daily activities as its medium, so that this is in accordance with the concept of applying contextual approaches. Contextual learning can realize meaningful learning that seeks to understand the relationship between material and daily life (Astuti et al., 2020; Nugroho, 2018). Students can learn well if students can relate their knowledge to the knowledge they receive or students can relate their knowledge to their daily lives. Contextual learning is designed based on the philosophical foundation of constructivism that emphasizes learning not just memorization, but students constructing their knowledge (Gitriani et al., 2018; Susiloningsih, 2016).

Contextual approaches are widely applied in the learning process because this approach allows for a learning process that optimizes the social intelligence of students (Mutakinati et al., 2018; Richey \& Klein, 2005). Awareness of the importance of using contextual approaches in the learning process is based on the fact that most students cannot associate the material studied with its utilization in real life (Hasanah et al., 2019; Sajnani \& Mayor, 2020). In the 21st century the role of teachers is required to be creative and innovative in utilizing technological sophistication to be applied in the learning process (Astalini et al., 2019; Seibert, 2020). Therefore, it is considered necessary to have a learning medium that utilizes technology to support learning by using contextual approaches.

Learning media as a tool used for means of channeling information about the subject matter, can help students experience the learning process in themselves to achieve learning goals (Ayuningsih, 2017; Fonda \& Sumargiyani, 2018). Using learning media can help generate students' motivation and interest to improve students' understanding (Falloon, 2020; Maharani, 2015). The use of learning media in the learning process is very important to be systematically designed so that the learning media is effective for use. Learning media can optimize the learning process of students in learning that is expected to optimize the learning outcomes achieved (Komikesari et al., 2020; Pratama \& Retnawati, 2018). Some reasons why learning media can optimize the learning process of students, namely teaching will attract more attention of students. So that it can add motivation to learning, teaching materials will be clearer meaning so that it can be better understood by students and allow students to be able to achieve learning purposes better (Bajrami \& Ismaili, 2016; Dewi et al., 2018). Learning methods will be more varied not only verbal communication through speech by teachers so that students do not get bored and teachers do not run out of energy especially if the teacher teaches for every hour of learning (Andriyani \& Suniasih, 2021; Prabaningrum \& Putra, 2019). Students do more learning activities because not only listen to the teacher's description but also other activities such as observing, doing, demonstrating, and others.

Contextual approach-based learning video media was developed to make it easier for students to understand science materials, especially changes in the form of objects. Learning videos or so-called audiovisual media are depictions or visualizations of the narrative of learning materials and packaged briefly (Bajrami \& Ismaili, 2016; Kamelia, 2019). Audiovisual is a multimedia that has elements that include sound, images, motion and text (Colasante \& Douglas, 2016; Kkese, 2020). The learning process with a contextual approach and assisted learning videos can help students construct material changes in the form of objects in daily life, so that students' learning outcomes can improve, can attract students in learning, and students more easily understand the material and do not get tired of following the learning. As for the things that distinguish the learning video media developed in this development research with other learning video media, namely the learning video developed has been designed with a contextual approach that can help students to learn more real. The 
advantage of this learning video developed is that it contains images that can be seen directly by students along with the explanation of the material so that it can visualize the concept that the teacher wants to convey so that the material is easier to understand by students and the learning purposes can be achieved optimally. The findings of previous research stated that learning videos would make it easier for students to learn (Fauzi et al., 2017; Larue \& Watling, 2021).Other research also states that learning videos will increase student enthusiasm and learning outcomes so that they are suitable for use (Handayani et al., 2017; Pradilasari et al., 2019).

Based on this, the learning media developed in the form of learning videos based on contextual approach. The development of learning video media is done so that students can learn independently and understand the teaching materials well. Learning video is develop using ADDIE development model (analyse, design, development, implementation, evaluation) which is considered suitable for developing learning videos. The purpose of the research is to develop the development of learning videos based on the Contextual Approach to the Contents of Science for Grade V Elementary School.

\section{Methods}

This type of research is development. This development research model uses the ADDIE model, consists of five steps, namely: analyze, design, development, implementation, and evaluation (Alnajdi, 2018; Cahyadi, 2019). Analysis is conducted to obtain information related to everything needed in the research. The analysis procedure in this development includes several stages, namely analyzing the needs, analyzing materials, determining Basic Competencies and Indicators, the stage of planning is carried out to facilitate the process of making products so that the products produced have a definite design. The design procedure includes several things such as data collection, video scripts and storyboards, this stage of development is carried out the production of learning videos with a predetermined design. Learning content creation, learning design is done in microsoft powerpoint and dubbing, backsound and editing are done in kine master application. The video is saved in MP4 format by adjusting the video resolution quality to make the image look clearer but has a size that is not too large so it is easy to share and save, the implementation stage at this stage after the product is validated by experts and produce products in a viable category then the product is ready to be implemented on the test subject. However, it cannot be implemented because covid 19 should not be crowded, this evaluation stage is done after the data at the implementation stage is collected. Evaluation is done in the form of sumative evaluation. Sumative evaluations are conducted to measure or assess learning products that include expert validation, individual trials, small group trials.

The test subject of this development research consists of several experts and students. The experts consist of learning content experts, namely lecturers who have qualifications in the field of elementary science, learning design experts and learning media experts, namely lecturers who are qualified in the field of educational technology and involve 3 students of grade V SD No. 5 Abiansemal to conduct individual tests and 12 students of grade V SD No. 5 Abiansemal to conduct small group trials. In this research, the data was obtained using the questionnaire distribution method. Questionnaire is a way of collecting data by providing a list of questions or statements to research subjects (Permana \& Nourmavita, 2017; Wulandari et al., 2020). Questionnaires are useful for obtaining information from research subjects related to the feasibility of learning videos made. In addition to using the questionnaire dissemination method, observation and interview methods (unstructured) are also used to determine the needs and characteristics of students who are used as test subjects in this development research. The success of interactive multimedia in this development research can be seen by conducting data analysis. 
The data obtained can be taken as a consideration in improving the learning video products that have been developed. In this development research used two data analysis techniques, namely qualitative descriptive data analysis, and quantitative decryptive data analysis. The data collection instrument in this development research is in the form of questionnaires. The questionnaire used consists of various statements made based on the aspects to be assessed. In this research used closed questionnaires, which are questionnaires with a choice of answers that have been available to respondents. Before the questionnaire is given to respondents, the questionnaire is consulted first with the supervisor, after the questionnaire is approved by the supervisor, the questionnaire is then submitted to the expert to be assessed eligibility so that the questionnaire can be called relevant or eligible to be used in testing the feasibility of a product development results. Here's a grid of polls for experts and test subjects.

Table 1. Questionnaire Grid for Learning Content Experts

\begin{tabular}{|c|c|c|}
\hline No & Aspects & Indicators \\
\hline \multirow{3}{*}{1} & \multirow{3}{*}{ Curriculum } & a. Material conformity with basic competencies Indicators \\
\hline & & b. Conformity of materials with learning indicators \\
\hline & & c. Conformity of materials with learning purposes \\
\hline \multirow{7}{*}{2} & \multirow{8}{*}{ Material } & a. Material truth \\
\hline & & b. Material downsity \\
\hline & & c. completeness of the material \\
\hline & & d. Depth of material \\
\hline & & e. Material conformity with student characteristics \\
\hline & & f. Materials supported with the right materials \\
\hline & & g. Easy-to-understand material \\
\hline & & a. Proper and consistent use of language \\
\hline 3 & Grammar & $\begin{array}{l}\text { b. The language used corresponds to the characteristics of the } \\
\text { student }\end{array}$ \\
\hline
\end{tabular}

Table 2. Questionnaire Gris for Learning Design Experts

\begin{tabular}{|c|c|c|}
\hline No & Components & Indicators \\
\hline 1 & Accuracy & $\begin{array}{l}\text { 1. Suitability of the video to the characteristics of the } \\
\text { student } \\
\text { 2. Conformity of materials with learning objectives } \\
\text { 3. The materials in the learning video are packaged } \\
\text { in detail } \\
\text { 4. Learning objectives in accordance with abcd } \\
\text { format }\end{array}$ \\
\hline 2 & Clarity & $\begin{array}{l}\text { 1. The language used is easy for students to } \\
\text { understand } \\
\text { 2. Clarity of description and discussion } \\
\text { 3. Clarity of content provided }\end{array}$ \\
\hline 3 & Interests/concerns & $\begin{array}{l}\text { 1. Videos motivate learning interests } \\
\text { 2. Increased students' attention to learning }\end{array}$ \\
\hline 4 & Test quality and assessment & 1. Evaluation coexistence with learning purposes \\
\hline 5 & Have an impact on students & 1. Facilitate students' understanding of the material \\
\hline 6 & Message Design & $\begin{array}{l}\text { 1. The color of the image is comfortable to look at } \\
\text { 2. Accuracy of the illustration in the description }\end{array}$ \\
\hline
\end{tabular}


Table 3. Questionnaire Grid for Learning Media Experts

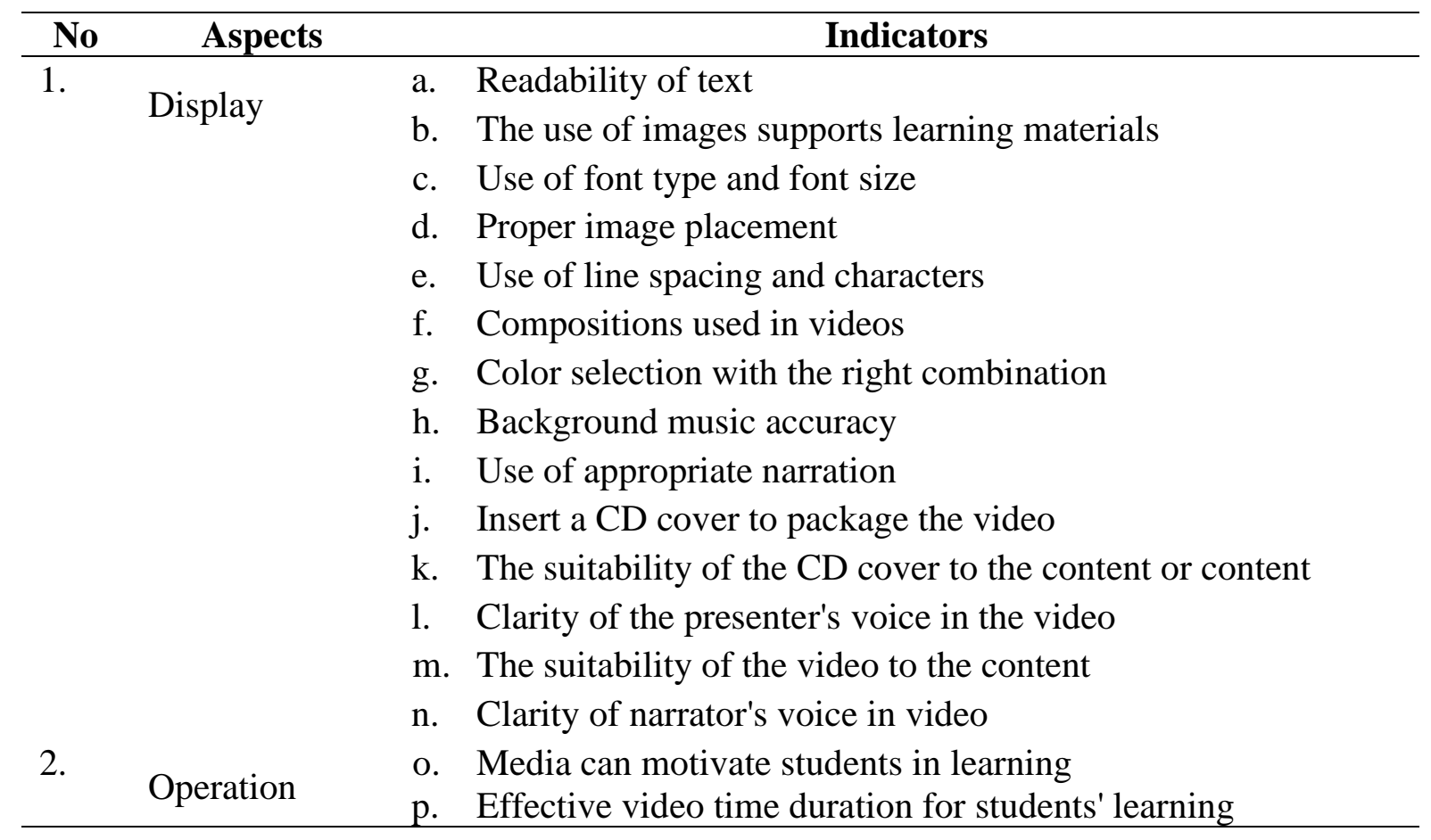

The responses or answers given by each respondent in the questionnaire were then analyzed using the Likert scale. Likert scale is used to develop instruments that measure one's attitude, perception, or opinion towards the design of a product or the process of making products and products that have been developed (Sugiyono, 2018). The Likert scale used in this development study has a gradation from very positive to very negative, which is the form of words, such as strongly agree, agree, disagree, and strongly disagree.

\section{Results and Discussion Results}

Design learning video development using ADDIE development model which includes analysis stage, design stage, development stage, implementation stage and evaluation stage. The process of developing this learning video has limitations on the development process, namely at the implementation stage that can not be done, because at the implementation stage can not do the implementation of products that are already feasible in the learning process to know the effectiveness of the product. This research was conducted during the covid-19 pandemic so it is not possible to carry out the process of face-to-face learning. The results of the development stage are as follows.

In the first stage of analysis, problem analysis is carried out in the learning process, student characteristics, material analysis. Analyzing the problems and characteristics of students conducted through interviews that are known that teachers have difficulty in creating learning media that can support online learning and easily accessible from home by students, especially for science learning contained in certain themes. To provide solutions to the problem, a learning video was developed that can help students in understanding the teaching materials. The results of the material analysis of the discussion together with the teacher are determined material changes in the form of objects as the content of the learning video developed.

In the second stage of the design stage, at this stage, the process of designing products to be developed includes the activities of creating flowcharts, creating storyboards and 
sketching learning implementation plans (RPP) that are used as a reference in carrying out learning activities that use contextual approaches assisted by learning media in the form of learning videos and compiling product assessment instruments in the form of questionnaires used by experts and students as test subjects to know the feasibility of learning videos developed.

In the third stage of development, product development is carried out starting with creating a learning video display, creating all components of the learning video, combining all components of the learning video (text, images, sound, etc.). If the learning video has been developed the next stage is to conduct product trials on test subjects that include learning content experts, learning design experts, learning media experts and students through individual and small group trials. Product trials are conducted to determine the feasibility of the product used in the learning process.

The last stage is the evaluation stage, the evaluation is carried out in a formative manner conducted during the development process, the purpose is to collect data from the development steps used to improve the product. At the analysis stage there is an evaluation process to analyze the needs in the learning process and student characteristics, at the design stage of the evaluation process for the completeness of learning video development planning and the evaluation process development stage to know the feasibility of products obtained from the test subjects to improve the products that have been developed.

Based on the results of a review by a learning content expert, this learning video gained a percentage of $95.83 \%$ who were in very good qualifications. It is obtained from several aspects, namely aspects of curriculum, material aspects, and aspects of grammar. Based on the results of a review by a learning design expert, this learning video gained a percentage of $94.23 \%$ in very good qualifications. It is obtained from several aspects, namely objectives, strategies, and evaluations. Based on the results of a review by learning media experts, this learning video gained a percentage of $85.00 \%$ in good qualifications and needed a slight revision. Product testing is the next step after passing the expert test. The product is tested to students covering several stages, namely individual trials, and small group trials. Individual trial results gained a percentage of $94.00 \%$ with very good qualifications, and from small group trials gained a percentage of $95.83 \%$ with very good qualifications. The results of the feasibility test of the learning video development product as a whole have a percentage with categories or qualifications are very good and good so it can be said that learning videos are feasible applying in the learning process.

\section{Discussion}

Learning video is an audiovisual media that is systematically designed with the applicable curriculum guidelines (Bajrami \& Ismaili, 2016; Kamelia, 2019). The development applies the principles of contextual approach so that the program allows students to observe the subject matter more easily and interestingly (Selvianiresa \& Prabawanto, 2017; Susanti et al., 2020). Learning video media is a media that belongs to the audiovisual media that is able to display information and messages through images and sounds that are delivered simultaneously (Hanif, 2020; Megawati \& Utami, 2020). The advantages of making video media are very widely used in learning and learning activities. Video media capable of showing objects, places and motion pictures (Andel et al., 2020; Colasante \& Douglas, 2016). In this development research, a contextual approach-based learning video media was developed that contains material changes in the form of objects in science learning in the theme of 7 sub-themes 1 of grade $\mathrm{V}$ elementary school learning that aims to assist teachers in the learning process. It is expected that the learning video media developed is more spurred the creativity of teachers in making learning media that suits the characteristics and needs of students. In addition, it is also expected to motivate students to be 
more enthusiastic in learning so that learning objectives are achieved. An interesting learning process will make students easier to understand the concept of (Abidah et al., 2020).

Students can learn well if students can connect their knowledge with the knowledge received or students can relate their knowledge into their daily lives (Alavudeen et al., 2021; Gjems, 2013). With the learning video that is designed correctly and clearly can certainly help students connect their knowledge with the knowledge they receive (Febriani, 2017; Kawka et al., 2021). Based on the results of a review by learning media experts, this learning video obtained a percentage of $85.00 \%$ who are in good qualifications, this is seen from several aspects namely the display and operation. In the 21 st century the role of teachers is required to be creative and innovative in utilizing technological sophistication to be applied in the learning process (Hirschman \& Wood, 2018; Nithyanantham et al., 2019). The latter is a discussion of the test results of students. Product testing is the next step after passing the expert test. The product can be tested to students covering several stages, namely individual trials, and small group trials. Individual trial results gained a percentage of $94.00 \%$ with very good qualifications, and from small group trials gained a percentage of $95.83 \%$ with very good qualifications. This is seen from several aspects, namely the appearance, material, motivation, and the operation. The use of technology in the learning process can be interpreted as a process to encourage active learning, construct knowledge, imkuiri in students making it possible to communicate remotely between teachers and students (Lavi et al., 2021; Malik, 2018).

The findings of previous research stated that learning videos would make it easier for students to learn (Fauzi et al., 2017; Larue \& Watling, 2021).Other research also states that learning videos will increase student enthusiasm and learning outcomes so that they are suitable for use (Handayani et al., 2017; Pradilasari et al., 2019). The findings of this development research are that learning videos can be said to be feasible using in the learning process in Elementary Schools when viewed from expert test results and trial results. The implications of this development research are (a) This study motivates or encourages teachers to utilize facilities and infrastructure in schools in the situation of pandemic covid 19 which has been rarely utilized. As well as being able to hone the ability of teachers in utilizing technological advances to advance education and indirectly this has an impact also on the ability of teachers in operating supporting media, namely laptops and LCD projectors, (b) The use of this learning video requires LCD Projector if it will be used in learning in the classroom, so that all students can see clearly the materials contained in the learning video in this science lesson content.

\section{Conclusion}

The research of learning video development based on contextual is worth using in the learning process. Eligibility was obtained based on expert scores and student trials obtained very good qualifications. Thus it can be concluded that the development of learning video contextual approach-based is feasible in the learning process.

\section{References}

Abidah, A., Hidaayatullaah, H. N., Simamora, R. M., Fehabutar, D., \& Mutakinati, L. (2020). The Impact of Covid-19 to Indonesian Education and Its Relation to the Philosophy of "Merdeka Belajar." Studies in Philosophy of Science and Education, 1(1), 38-49. https://doi.org/10.46627/sipose.v1i1.9

Alavudeen, S. S., Easwaran, V., Mir, J. I., Shahrani, S. M., Ahmed Mohammed Almodeer Aseeri, A. A., Khan, N. A., \& Asiri, A. A. (2021). The influence of COVID-19 related psychological and demographic variables on the effectiveness of e-learning among 
health care students in the southern region of Saudi Arabia. Saudi Pharmaceutical Journal. https://doi.org/10.1016/j.jsps.2021.05.009

Alnajdi, S. M. (2018). The Effectiveness of Designing and Using a Practical Interactive Lesson based on ADDIE Model to Enhance Students' Learning Performances in University of Tabuk. Journal of Education and Learning, 7(6), 212. https://doi.org/10.5539/jel.v7n6p212

Andel, S. A., de Vreede, T., Spector, P. E., Padmanabhan, B., Singh, V. K., \& Vreede, G. J. de. (2020). Do social features help in video-centric online learning platforms? A social presence perspective. Computers in Human Behavior, 113(April), 106505. https://doi.org/10.1016/j.chb.2020.106505

Andriyani, N. L., \& Suniasih, N. W. (2021). Development Of Learning Videos Based On Problem-Solving Characteristics Of Animals And Their Habitats Contain in Science Subjects On 6th-Grade. Journal of Education ..., 5(1), 37-47. https://doi.org/10.23887/jet.v5i1.32314

Anif, S., Sutopo, A., \& Prayitno, H. J. (2020). Lesson study validation: Model for social and natural sciences teacher development in the implementation of national curriculum in Muhammadiyah schools, Indonesia. Universal Journal of Educational Research, 8(1), 253-259. https://doi.org/10.13189/ujer.2020.080132

Astalini, A., Darmaji, D., Kurniawan, W., Anwar, K., \& Kurniawan, D. A. (2019). Effectivenes of Using E-Module and E-Assessment. International Journal of Interactive Mobile Technologies (IJIM), 13(09), 21-39. https://doi.org/10.3991/ijim.v13i09.11016

Astuti, J., Novita, M., \& Ismail, M. S. (2020). Peningkatan Motivasi Belajar Menggunakan Contextual Teaching and Learning di Madrasah Ibtidaiyah Swasta Raudhatul Mujawwidin Tebo. Jurnal Educative: Journal Of Educational Studies, 5(1). https://doi.org/10.30983/educative.v5i1.1630

Ayuningsih, K. (2017). Pengaruh Video Animasi Terhadap Hasil Belajar Kognitif Pada Mata Pelajaran IPS Materi Menghargai Jasa Pahlawan di Kelas V SDN Sidokumpul Sidoarjo. JICTE (Journal of Information and Computer Technology Education), 1(1), 43. https://doi.org/10.21070/jicte.v1i1.1129

Bajrami, L., \& Ismaili, M. (2016). The Role of Video Materials in EFL Classrooms. Procedia - Social and Behavioral Sciences, 232(April), 502-506. https://doi.org/10.1016/j.sbspro.2016.10.068

Cahyadi, R. A. H. (2019). Pengembangan bahan ajar berbasis ADDIE model. Halaqa: Islamic Education Journal, 3(1), 35-42. https://doi.org/10.21070/halaqa.v3i1.2124

Chandra, A. Y., Kurniawan, D., \& Musa, R. (2020). Perancangan Chatbot Menggunakan Dialogflow Natural Language Processing (Studi Kasus: Sistem Pemesanan pada Coffee

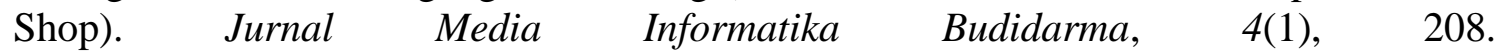
https://doi.org/10.30865/mib.v4i1.1505

Colasante, M., \& Douglas, K. (2016). Prepare-participate-connect: Active learning with video annotation. Australasian Journal of Educational Technology, 32(4), 68-91. https://doi.org/10.14742/ajet.2123

Desnita, D., \& Susanti, D. (2017). Science Process Skills-Based Integrated Instructional Materials to Improve Student Competence Physics Education Prepares Learning Plans on Teaching Skills Lectures. Jurnal Penelitian \& Pengembangan Pendidikan Fisika, 3(1), 35. https://doi.org/10.21009/1.03105

Dewi, N. R., Kannapiran, S., \& Wibowo, S. W. A. (2018). Development of digital storytelling-based science teaching materials to improve students' metacognitive ability. Jurnal Pendidikan IPA Indonesia, 7(1), 16-24. https://doi.org/10.15294/jpii.v7i1.12718

Falloon, G. (2020). From digital literacy to digital competence: the teacher digital competency (TDC) framework. Educational Technology Research and Development, 
68(5), 2449-2472. https://doi.org/10.1007/s11423-020-09767-4

Fauzi, H. A., Komalasari, K., \& Malik, Y. (2017). Utilization of Audio Visual Media to Improve Student Learning Result in IPS Learning. International Journal Pedagogy of Social Studies, 2(1), 88-103. https://doi.org/10.17509/ijposs.v2i1.8666

Febriani, C. (2017). Pengaruh Media Video terhadap Motivasi dan Hasil Belajar Kognitif Pembelajaran IPA Kelas V Sekolah Dasar. Jurnal Prima Edukasia, 5(1), 11-21. https://doi.org/10.21831/jpe.v5i1.8461

Fonda, A., \& Sumargiyani, S. (2018). The Developing Math Electronic Module With Scientific Approach Using Kvisoft Flipbook Maker Pro For Xi Grade Of Senior High School Students. Infinity Journal, $7(2), \quad 109-122$. https://doi.org/10.22460/infinity.v7i2.p109-122

Gitriani, R., Aisah, S., Hendriana, H., \& Herdiman, I. (2018). Pengembangan Lembar Kerja Siswa Berbasis Pendekatan Kontekstual pada Materi Lingkaran Untuk Siswa SMP. Jurnal Review Pembelajaran Matematika, 3(1), 40-48. https://doi.org/10.15642/jrpm.2018.3.1.40-48

Gjems, L. (2013). Teaching in ECE: Promoting children's language learning and cooperation on knowledge construction in everyday conversations in kindergarten. Teaching and Teacher Education, 29(1), 39-45. https://doi.org/10.1016/j.tate.2012.08.008

Gordon, N., Brayshaw, M., \& Grey, S. (2013). Maximising gain for minimal pain: Utilising natural game mechanics. Innovation in Teaching and Learning in Information and Computer Sciences, 12(1), 27-38. https://doi.org/10.11120/ital.2013.00004

Handayani, N. M. D., Ganing, N. N., \& Suniasih, N. W. (2017). Model Pembelajaran Picture and Picture Berbantuan Media Audio-Visual Terhadap Pengetahuan IPA. Journal of Education Technology, 1(3), 176. https://doi.org/10.23887/jet.v1i3.12502

Hanif, M. (2020). The development and effectiveness of motion graphic animation videos to improve primary school students' sciences learning outcomes. International Journal of Instruction, 13(4), 247-266. https://doi.org/10.29333/iji.2020.13416a

Hasanah, N., Buchori, A., Prasetyowati, D., \& Nursyahidah, F. (2019). Efektivitas model pembelajaran Relating, Experiencing, Applying, Cooperating, Transferring (REACT) dan reciprocal teaching berbantuan game edukasi. Pythagoras: Jurnal Pendidikan Matematika, 14(1). https://doi.org/10.21831/pg.v14i1.17157

Hirschman, K., \& Wood, B. (2018). 21st century learners: Changing conceptions of knowledge, learning and the child. The New Zealand Annual Review of Education, 23(June), 20. https://doi.org/10.26686/nzaroe.v23i0.5280

Hwang, G. J., Yang, L. H., \& Wang, S. Y. (2013). A concept map-embedded educational computer game for improving students' learning performance in natural science courses. Computers \& Education, 69. https://doi.org/10.1016/j.compedu.2013.07.008

I Made Arnawa, A. A. S. W. (2017). Pengembangan Perangkat Pembelajaran Matematika Dengan Pendekatan Contextual Teaching And Learning Untuk Meningkatkan Kemampuan Pemecahan Masalah Peserta Didik Kelas XI. Jurna Nasional Pendidikan Matematika, 1(2). https://doi.org/10.33603/jnpm.v1i2.535.

Ikeda, K., Nollet, K. E., Vrielink, H., \& Ohto, H. (2018). Apheresis education and certification for nurses. In Transfusion and Apheresis Science (Vol. 57, Issue 5, pp. 14). https://doi.org/10.1016/j.transci.2018.09.010

Kamelia, K. (2019). Using Video as Media of Teaching in English Language Classroom: Expressing Congratulation and Hopes. Utamax: Journal of Ultimate Research and Trends in Education, 1(1), 34-38. https://doi.org/10.31849/utamax.v1i1.2742

Kawka, M., MH.Gall, T., Fang, C., Liu, R., \& Jiao, R. (2021). Intraoperative video analysis and machine learning models will change the future of surgical training. Intelligent Surgery, 1(1). https://doi.org/10.1016/j.isurg.2021.03.001 
Kivunja, C. (2013). Embedding Digital Pedagogy in Pre-Service Higher Education to Better Prepare Teachers for the Digital Generation. International Journal of Higher Education, 2(4), 131-142. https://doi.org/10.5430/ijhe.v2n4p131

Kkese, E. (2020). McGurk effect and audiovisual speech perception in students with learning disabilities exposed to online teaching during the COVID-19 pandemic. Medical Hypotheses, 144(July), 110233. https://doi.org/10.1016/j.mehy.2020.110233

Komikesari, H., Mutoharoh, M., Dewi, P. S., Utami, G. N., Anggraini, W., \& Himmah, E. F. (2020). Development of e-module using flip pdf professional on temperature and heat material. Journal of Physics: Conference Series, 1572(1). https://doi.org/10.1088/17426596/1572/1/012017

Lai, A. F., Chen, C. H., \& Lee, G. Y. (2019). An augmented reality-based learning approach to enhancing students' science reading performances from the perspective of the cognitive load theory. British Journal of Educational Technology, 50(1), 232-247. https://doi.org/10.1111/bjet.12716

Larue, G. S., \& Watling, C. N. (2021). Acceptance of visual and audio interventions for distracted pedestrians. Transportation Research Part F: Traffic Psychology and Behaviour, 76. https://doi.org/10.1016/j.trf.2020.12.001

Lavi, R., Tal, M., \& Dori, Y. J. (2021). Perceptions of STEM alumni and students on developing 21st century skills through methods of teaching and learning. Studies in Educational Evaluation, 70, 1-11. https://doi.org/10.1016/j.stueduc.2021.101002

Lo, J.-H., Lai, Y.-F., \& Hsu, T.-L. (2021). The Study of AR-Based Learning for Natural Science Inquiry Activities in Taiwan's Elementary School from the Perspective of Sustainable Development. Sustainability, 13(3). https://doi.org/10.3390/su13116283

Maharani, Y. S. (2015). Efektivitas Multimedia Pembelajaran Interaktif Berbasis Kurikulum 2013. Indonesian Journal of Curriculum and Educational Technology Studies, 3(1), 3140. https://doi.org/10.15294/ijcets.v3i1.8683

Maison, M., Haryanto, H., Ernawati, M. D. W., Ningsih, Y., Jannah, N., Puspitasari, T. O., \& Putra, D. S. (2020). Comparison of student attitudes towards natural sciences. International Journal of Evaluation and Research in Education, 9(1), 54-61. https://doi.org/10.11591/ijere.v9i1.20394

Malik, R. S. (2018). Educational Challenges in 21st Century and Sutainable Development. Journal of Sustainable Development Education and Research, 2(1), 9-20. https://doi.org/10.17509/jsder.v2i1.12266

Marhayani, D. A. (2016). Development of Character Education Based on Local Wisdom in Indegenous People Tengahan Sedangagung. JETL (Journal Of Education, Teaching and Learning), 1(2), 66. https://doi.org/10.26737/jetl.v1i2.40

Marshel, J., \& Ratnawulan. (2020). Analysis of Students Worksheet (LKPD) integrated science with the theme of the motion in life using integrated connected type 21st century learning. Journal of Physics: Conference Series, 1481(1). https://doi.org/10.1088/17426596/1481/1/012046

Megawati, \& Utami. (2020). English Learning with Powtoon Animation Video. Journal of Education Technology, 4(2), 110. https://doi.org/10.23887/jet.v4i2.25096

Mpungose, C. B. (2021). Lecturers' reflections on use of Zoom video conferencing technology for e-learning at a South African university in the context of coronavirus. African Identities. https://doi.org/10.1080/14725843.2021.1902268

Mutakinati, L., Anwari, I., \& Yoshisuke, K. (2018). Analysis of students' critical thinking skill of middle school through stem education project-based learning. Jurnal Pendidikan IPA Indonesia, 7(1), 54-65. https://doi.org/10.15294/jpii.v7i1.10495

Nithyanantham, V., Paulmony, R., \& Ramadan H., S. (2019). Self-Perspective of 21st Century Educators: A Challenge in The Globalised Educational World. International 
Journal of Educational Research Review, 4(3). https://doi.org/10.24331/ijere.573869

Nugroho, R. (2018). Pengembangan Perangkat Pembelajaran Dengan Pendekatan Contextual

Teaching And Learning Untuk Meningkatkan Motivasi Dan Hasil Belajar Bagi Siswa Kelas Iv Sekolah Dasar. Jurnal Bidang Pendidikan Dasar, 2(2). https://doi.org/10.21067/jbpd.v2i2.2638

Permana, E. P., \& Nourmavita, D. (2017). Pengembangan Multimedia Interaktif Pada Mata Pelajaran Ipa Materi Mendeskripsikan Daur Hidup Hewan Di Lingkungan Sekitar Siswa Kelas Iv Sekolah Dasar. Jurnal PGSD, 10(2), 79-85. https://doi.org/10.33369/pgsd.10.2.79-85

Prabaningrum, \& Putra. (2019). Pengaruh Model Pembelajaran Kooperatif Team Assisted Individualization Berbantuan Media Semi Konkret Terhadap Kompetensi Pengetahuan Matematika. Jurnal Ilmiah Sekolah Dasar, 3(4), 414. https://doi.org/10.23887/jisd.v3i4.21775

Pradilasari, L., Gani, A., \& Khaldun, I. (2019). Pengembangan Media Pembelajaran Berbasis Audio Visual pada Materi Koloid Untuk Meningkatkan Motivasi dan Hasil Belajar Siswa SMA. Jurnal Pendidikan Sains Indonesia, 7(1), 9-15. https://doi.org/10.24815/jpsi.v7i1.13293

Pratama, G. S., \& Retnawati, H. (2018). Urgency of Higher Order Thinking Skills (HOTS) Content Analysis in Mathematics Textbook. Journal of Physics: Conference Series, 1097(1). https://doi.org/10.1088/1742-6596/1097/1/012147

Puspitarini, Y. D., \& Hanif, M. (2019). Using Learning Media to Increase Learning Motivation in Elementary School. Anatolian Journal of Education, 4(2), 53-60. https://doi.org/10.29333/aje.2019.426a

Rahayu, S. E., \& Febriaty, H. (2017). Penerapan Model Pembelajaran Contextual Teaching And Learning (CTL) Untuk Meningkatkan Pemahaman Materi Pasar Valuta Asing Pada Mata Kuliah Ekonomi Internasional 2 (Studi Mahasiswa Semester 5 Jurusan Ekonomi Pembangunan Fakultas Ekonomi UMSU). Jurnal Ilmiah Manajemen Dan Bisnis, 17(2), 94-107. https://doi.org/10.30596/jimb.v17i2.960

Richey, R. C., \& Klein, J. D. (2005). Developmental research methods: Creating knowledge from instructional design and development practice. Journal of Computing in Higher Education, 16(2), 23-38. https://doi.org/10.1007/BF02961473

Rusli, R., Rahman, A., \& Abdullah, H. (2020). Student perception data on online learning using heutagogy approach in the Faculty of Mathematics and Natural Sciences of Universitas Negeri Makassar, Indonesia. Data in Brief, 29, 105152. https://doi.org/10.1016/j.dib.2020.105152

Sajnani, N., \& Mayor, C. et al. (2020). Aesthetic presence: The role of the arts in the education of creative arts therapists in the classroom and online. Arts in Psychotherapy, 69(February), 101668. https://doi.org/10.1016/j.aip.2020.101668

Seibert, S. A. (2020). Problem-based learning: A strategy to foster generation Z's critical thinking and perseverance. Teaching and Learning in Nursing, 000, 2-5. https://doi.org/10.1016/j.teln.2020.09.002

Selvianiresa, D., \& Prabawanto, S. (2017). Contextual Teaching and Learning Approach of Mathematics in Primary Schools. Journal of Physics: Conference Series, 895(1). https://doi.org/10.1088/1742-6596/895/1/012171

Setiawan, Innatesari, D. K., Sabtiawan, W. B., \& Sudarmin, S. (2017). The development of local wisdom-based natural science module to improve science literation of students. Jurnal Pendidikan IPA Indonesia, 6(1), 49-54. https://doi.org/10.15294/jpii.v6i1.9595

Shodiq, I. J., \& Zainiyati, H. S. (2020). Pemanfaatan Media Pembelajaran E-Learning Menggunakan Whastsapp Sebagai Solusi Ditengah Penyebaran Covid-19 Di Mi Nurulhuda Jelu. Al-Insyiroh: Jurnal Studi Keislaman, 6(2), 144-159. 


\section{https://doi.org/10.35309/alinsyiroh.v6i2.3946}

Suartama, I. K. (2016). Evaluasi dan Kriteria Kualitas Multimedia Pembelajaran. Universitas Pendidikan Ganesha.

Subali, B., Kumaidi, Aminah, N. S., \& Sumintono, B. (2019). Student achievement based on the use of scientific method in the natural science subject in elementary school. Jurnal Pendidikan IPA Indonesia, 8(1), 39-51. https://doi.org/10.15294/jpii.v8i1.16010

Sugiyono. (2018). Metode Penelitian Kuantitatif,Kualitatif dan R\&D. In ke-26.

Suryawati, E., \& Osman, K. (2018). Contextual learning: Innovative approach towards the development of students' scientific attitude and natural science performance. Eurasia Journal of Mathematics, Science and Technology Education, 14(1), 61-76. https://doi.org/10.12973/ejmste/79329

Susanti, N., Yennita, Y., \& Azhar, A. (2020). Development of Contextual Based Electronic Global Warming Modules Using Flipbook Applications as Physics Learning Media in High Schools. Journal of Educational Sciences, 4(3), 541. https://doi.org/10.31258/jes.4.3.p.541-559

Susiloningsih, W. (2016). Model Pembelajaran CTL (Contextual Teaching and Learning) dalam Meningkatkan Hasil Belajar Mahasiswa PGSD Pada MataKuliah Konsep IPS Dasar. PEDAGOGIA: Jurnal Pendidikan, 57. https://doi.org/10.21070/pedagogia.v5i1.89

Tapingkae, P., Panjaburee, P., Hwang, G.-J., \& Srisawasdi, N. (2020). Effects of a formative assessment-based contextual gaming approach on students' digital citizenship behaviours, learning motivations, and perceptions. Computers \& Education, 159. https://doi.org/10.1016/j.compedu.2020.103998

Wulandari, I. G. A. A. M., Sudatha, I. G. W., \& Simamora, A. H. (2020). Pengembangan Pembelajaran Blended Pada Mata Kuliah Ahara Yoga Semester II di IHDN Denpasar. Jurnal Edutech Undiksha, 8(1), 1. https://doi.org/10.23887/jeu.v8i1.26459

Zendler, A., \& Greiner, H. (2020). The effect of two instructional methods on learning outcome in chemistry education: The experiment method and computer simulation. Education for Chemical Engineers. https://doi.org/10.1016/j.ece.2019.09.001

Zhang, H., Daim, T., \& Zhang, Y. (Peggy). (2021). Integrating patent analysis into technology roadmapping: A latent dirichlet allocation based technology assessment and roadmapping in the field of Blockchain. Technological Forecasting and Social Change, 167. https://doi.org/10.1016/j.techfore.2021.120729

Zulfiani, Suwarna, I. P., \& Sumantri, M. F. (2020). Science adaptive assessment tool: Kolb's learning style profile and student's higher order thinking skill level. Jurnal Pendidikan IPA Indonesia, 9(2), 194-207. https://doi.org/10.15294/jpii.v9i2.23840 